\title{
Correlation between Left Ventricular Eccentricity Index and Mean Pulmonary Arterial Pressure in Secundum Type Atrial Septal Defect Adult Patients
}

\author{
Citra Dewi Wahyu Fitria, Azhafid Nashar, Dyah Wulan Anggrahini, Anggoro Budi Hartopo, \\ Hasanah Mumpuni, Lucia Kris Dinarti* \\ Department of Cardiology and Vascular Medicine, Faculty of Medicine, Public Heath and Nursing, \\ Universitas Gadjah Mada - Dr. Sardjito Hospital Yogyakarta, Indonesia
}

Corresponding author:

Lucia Kris Dinarti, MD, - email: kris_dinarti@ugm.ac.id

Department of Cardiology and Vascular Medicine, Faculty of Medicine, Public Heath and Nursing, Universitas Gadjah

Mada - Dr. Sardjito Hospital Yogyakarta, Indonesia

Jalan Farmako Sekip Utara, Yogyakarta, Indonesia 55281

Manuscript submitted: April 7, 2018; Revised and accepted: June 10, 2018

\section{ABSTRACT}

Background: Secundum type atrial septal defect (ASD) is the most common adult congenital heart disease. Hemodynamically, ASD result in a left-to-right shunt that causes right heart volume overload. This condition affects interventricular septal position and shape. Left ventricular (LV) eccentricity index (EI) suggests right ventricle (RV) overload when this ratio is $>1.0$. The aim of this study was to assess correlation between LV EI and mean pulmonary arterial pressure (mPAP) in secundum type ASD patients.

Methods: We conducted a cross sectional study from ASD patients registry data. We enrolled subjects with secundum type ASD from the complete registry data. The LV El was calculated from transthoracal echocardiography. The MPAP was measured by right heart catheterization as a gold standart. The correlation was performed by Spearman correlation test.

Results: There were 40 adult secundum type ASD patients participated. The mean LV El in enddiastolic was $1.55 \pm 0.39$ and LV El in end-systolic was $1.75 \pm 0.58$. The median value of mPAP was $29(12-99) \mathrm{mmHg}$. There was a moderate strength, positive and significant correlation between LV El in end-diastolic and mPAP $(r=0.37, p=0.018)$. The correlation was more significant and stronger between LV El in end-systolic and mPAP $(r=0.52, p=0.001)$.

Conclusion: There was sufficiently strong and significant correlation between LV El in both end-diastolic and end-systolic phase with mPAP in adult secundum type ASD.

Keywords: eccentricity index; mean pulmonary arterial pressure; secundum atrial septal defect; pulmonary arterial hypertension

\section{INTISARI}

Latar Belakang: Defek septum atrium mengakibatkan aliran pirau dari jantung kiri ke kanan sehingga terjadi berlebihnya volume darah pada jantung kanan. Kondisi ini mempengaruhi posisi septum interventrikel dan bentuk ventrikel kiri. Eccentricity index $(\mathrm{EI})$ ventrikel kiri > 1,0 menunjukkan volume ventrikel kanan yang berlebih. Tujuan dari penelitian ini untuk menilai korelasi antara El ventrikel kiri dan mean pulmonary arterial pressure (mPAP) pada pasien DSA tipe sekundum dewasa.

Metode: Penelitian ini merupakan penelitian potong lintang, dengan mencuplik data dari register DSA dewasa di RSUP. Dr. Sardjito, Yogyakarta, periode Juli 2012 sampai dengan Juli 2013. Subjek penelitian adalah pasien DSA tipe sekundum dewasa. Nilai El ventrikel kiri dievaluasi dengan ekokardiografi transthorakal. Nilai mPAP dievaluasi dengan kateterisasi jantung kanan sebagai baku emas.

Hasil: Terdapat 40 subjek dalam penelitian ini. Sebagian besar wanita $(80 \%)$ dengan rerata usia 37,6 tahun. Nilai rerata El pada akhir diastolik adalah 1,55 $\pm 0,39$ dan rerata El pada akhir sistolik adalah $1,75 \pm 0,58$. Nilai median mPAP adalah $29(12-99) \mathrm{mmHg}$. Terdapat korelasi yang 
signifikan antara nilai El pada akhir diastolik dan mPAP $(r=0,37, p=0,018)$. Terdapat korelasi yang lebih kuat dan signifikan antara nilai El pada akhir sistolik dan mPAP $(r=0,52, p=0,001)$. Simpulan: Terdapat korelasi yang cukup kuat dan signifikan antara El ventrikel kiri pada fase akhir diastolik dan akhir sistolik dengan tekanan arteri paru rata-rata pada pasien DSA sekundum dewasa.

\section{INTRODUCTION}

Secundum type atrial septal defect (ASD) is the most common congenital heart disease encounters in adult. Hemodynamically, ASD results in a left-to-right shunting flow that causes right heart volume overload. This condition are known to affect interventricular septal position and shape. ${ }^{1}$ In addition, right ventricular volume overload causes an increase in pulmonary blood flow, resulting in the damage of endothelial cells that subsequently causes leukocyte activation and inflammatory mediators production. ${ }^{2}$ This process results in vasoconstriction and vascular hypertrophy, which in the long term may cause pulmonary arterial hypertension (PAH). ${ }^{2}$

A PAH is defined as an elevated mean pulmonary arterial pressure (mPAP) above 25 $\mathrm{mmHg}$, pulmonary capillary wedge pressure less than $15 \mathrm{mmHg}$ without decreased of cardiac output, and pulmonary vascular resistance more than 3 Wood Unit at rest as assessed by right heart catheterization ( $\mathrm{RHC})$, the invasive procedure. ${ }^{3}$ Doppler echocardiography becomes a non invasive modality that enables the valid estimation of pulmonary arterial pressure (PAP). In the absence of pulmonary flow obstruction, tricuspid regurgitation peak velocity (TRPV) and right ventricular outflow tract acceleration time have linear positive and negative correlations, respectively, with systolic PAP (sPAP) and mPAP measured by $\mathrm{RHC}$, as a gold standard. ${ }^{4}$

Chronic dilatation of the right ventricle, such as in an isolated RV volume overload, results in progressive lengthening from the base to the apex as well as from the free wall to the septum dimensions of the right ventricle. The RV apex progressively replacing the left ventricle as the true apex of the heart. Using transthoracal echocardiography, in the parasternal short-axis view, the left ventricle assumes a D-shaped cavity due to ventricular septum flattening and progressively loses its convexity with respect to the center of the RV cavity during diastole. ${ }^{5}$ The RV pressure overload also shifs the septum leftward from the center of the RV toward the center of the $\mathrm{LV}$, resulting in flattening of the interventricular septum and a D-shaped short-axis LV cavity, especially at systolic phase. This relationship between the LV and RV can be quantitated on the basis of the ratio between the LV anteroposterior dimension and the septolateral dimension, dubbed eccentricity index $(\mathrm{El}) .^{5}$ The value of $\mathrm{El}>1.0$ is abnormal and suggests RV overload. ${ }^{5}$

The shape and pattern of the interventricular septum is dependent on the relative pressure gradient between the RV and LV at each stage during cardiac cycle. ${ }^{5}$ Ryan et al. (1986) examined the $\mathrm{El}$ in patients with right ventricular volume overload and right ventricular pressure overload. ${ }^{6}$ From this study, it was shown that El had abnormal movement of the interventricular septum, El at enddiastolic increased significantly in patients with $R V$ volume overload and El at end-systolic increased significantly in patients with $\mathrm{RV}$ pressure overload. However, this study did not correlate El value with pulmonary artery pressure. There is few studies assessing the correlation between the LV EI value and mPAP in adult patients with secundum type ASD. The aim of this study is to investigate the correlation between the value of $\mathrm{El}$, measured by transthoracl echocardiography as a non invasive modality, and mPAP, measured with RHC. The expectation is that a non invasive examination by transthoracal echocardiography of El could be one modality to estimate the $\mathrm{PAH}$ in patients with secundum type ASD. 


\section{METHODS}

This study was a cross sectional study, by using the data available from the registry of adult ASD conducted at Dr. Sardjito Hospital, Yogyakarta, Indonesia from the period of July 2012 to July 2013. Subjects were patients with secundum type ASD who have been undergone right-heart catheterization. The subjects data retrieved from the registry were medical history, demography, physical examination, electrocardiogram, echocardiogram, and RHC. Those with complete data were selected as the subjects for this research. The subjects were given informed consent to be included in the research.

All subjects underwent transthoracal echocardiography examination performed by 2 sonographers who have hab undergone conformity test for the evaluation of patients with ASD to be included in the registry. The echocardiography machine was VIVID 7 (GE, USA). The results of echocardiogram were validated by a cardiologist consultant of echocardiography. The size of the defect, the dimension of the right atrium, right ventricle, left atrium and left ventricle, the right ventricular systolic function and left ventricular diastolic function, tricuspid valve gradient, and the estimated right ventricular systolic pressure were evaluated. The diameter of defect was taken from the mean of the minimum and maximum distance of the interatrial gap. The dimension of right atrium was taken by measuring the diameter from the apical 4-chamber view with a maximum distance from the wall mid-right atrium to interarterial septum, the minor axis that was perpendicular to the major axis. Right ventricular (RV) dimension was measured with apical 4-chamber view in the end-diastolic phase. The RV dimension was the dimension of a maximum of one-third of the basal $\mathrm{RV}$ on the minor axis, perpendicular to the major axis. The LV ejection fraction was measured using a linear M-mode and presented as a percentage (\%). The TAPSE was measured from the lateral tricuspid annulus, using the M-mode. The TAPSE value $<16 \mathrm{~mm}$ indicated RV systolic dysfunction. Tricuspid regurgitation was evaluated qualitatively using color flow imaging. Pressure gradient that passed through the tricuspid valve was measured by continuous wave Doppler color.

For measurement of $\mathrm{LV} E \mathrm{El}$, the ratio of the minor axis parallel to the left ventricular septum (D2) to the minor axis perpendicular to the septum (D1) on the parasternal short-axis view in the high level of papillary muscle of the left ventricle was assessed (Figure 1). The El was measured at the time of end-diastolic and end-systolic.
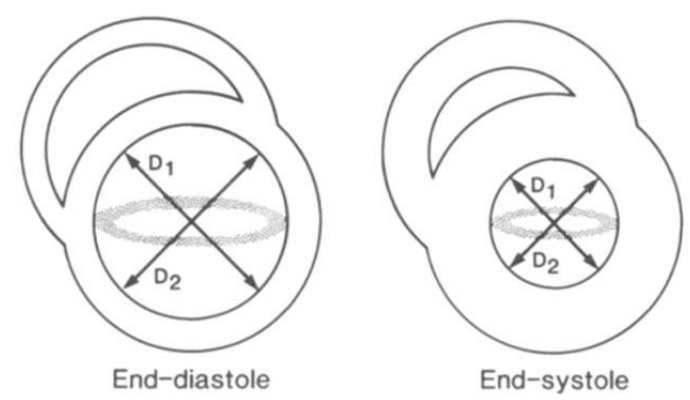

Eccentricity Index $=D_{2} / D_{1}$

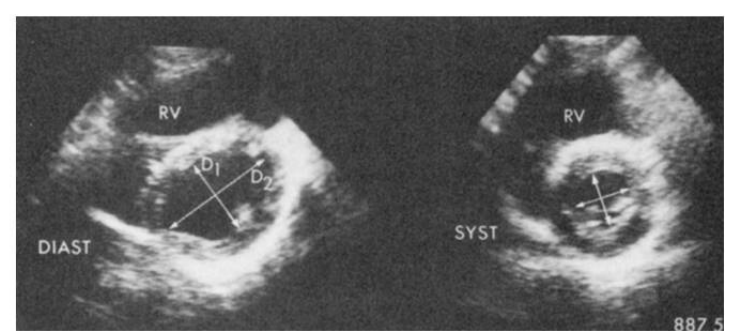

Figure 1. Measurement of LV EI based on methods by Ryan et al. (1986) with transthoracal echocardiography ${ }^{6}$

The right heart catheterisation ( $\mathrm{RHC}$ ) examination was performed by cardiologist consultants using standard technique in the cathlab. From the RHC examination, we assessed mPAP, pulmonary arterial resistance index (PARI) and flow ratio (FR) by using standardized formulae.

For statisctics analysis, the data of the subjects were displayed as percentage for categorical data, mean \pm standard deviations 
(SD) for normally distributed continuous data and median (minimum value to maximum value) for not normally distributed continuous data. The magnitude of correlation between El with mPAP was analyzed by Spearman correlation test. The analysis was performed with SPSS software ver. 20. The statistical significance was determined when $p$ value $<0.05$

\section{RESULTS}

We examined the data of 40 adult patients with secundum type ASD. Most of them were females $(80 \%)$ with mean age at examination was $37.68 \pm 14.73$ years. The median value of mPAP was 29 (12-99) $\mathrm{mmHg}$. Mean value of El at the end-diastolic was $1.55 \pm 0.39$ and at the end-systolic was $1.75 \pm 0.58$. Table 1 shows the baseline characteristics of research subjects.

There was a significant positive correlation between the value of El at end-diastolic and
mPAP $(r=0.37, p=0.018)$. The $r$ value indicated a moderate strength correlation between the value of El at end-diastolic and mPAP. Figure 1 showed the scatter plot of the El at end-diastolic and $\mathrm{mPAP}$.

There was also a significant positive correlation between the value of $\mathrm{El}$ at endsystolic and mPAP $(r=0.52, p=0.001$. The $r$ value indicated a more stronger correlation between value of El at end-systolic and mPAP. Figure 2 showed the scatter plot of the El at endsystolic and mPAP.

\section{DISCUSSION}

The result of our study showed that there was a sufficiently strong correlation between El and $\mathrm{mPAP}$ in patients with secundum type ASD. It indicated that non invasive parameter using El could predict the increased pulmonary artery pressure in secundum type ASD. Furthermore,

Table 1. The demography, echocardiography and right heart catheter parameters of the subjects

\begin{tabular}{|c|c|}
\hline Parameters & Value \\
\hline \multicolumn{2}{|l|}{ Demography } \\
\hline Age, mean $\pm S D$ & $37.68 \pm 14.73$ \\
\hline \multicolumn{2}{|l|}{ Gender, n (\%) } \\
\hline Male & $8(20 \%)$ \\
\hline Female & $32(80 \%)$ \\
\hline \multicolumn{2}{|l|}{ Echocardiographic result } \\
\hline Defect size $(\mathrm{mm})$, mean $\pm S D$ & $26.50 \pm 7.50$ \\
\hline Right atrial diameter $(\mathrm{mm})$, mean $\pm S D$ & $45.55 \pm 7.85$ \\
\hline Right ventricle diameter $(\mathrm{mm})$, mean $\pm S D$ & $44.88 \pm 7.06$ \\
\hline TAPSE $(m m)^{*}$ & $27(13-39)$ \\
\hline TVG $(\mathrm{mmHg})^{*}$ & $48.5(20-151)$ \\
\hline $\operatorname{RVSP}(\mathrm{mmHg})^{*}$ & $58.5(25-165)$ \\
\hline LVEDd (mm), mean \pm SD & $35.88 \pm 6.09$ \\
\hline Left atrial diameter $(\mathrm{mm})$, mean $\pm S D$ & $35.63 \pm 7.14$ \\
\hline Ejection fraction (\%),mean \pm SD & $67.65 \pm 8.43$ \\
\hline El end-diastolic, mean $\pm S D$ & $1.55 \pm 0.39$ \\
\hline El end-systolic, mean $\pm S D$ & $1.75 \pm 0.58$ \\
\hline \multicolumn{2}{|l|}{ Right heart catheterisation result } \\
\hline $\mathrm{PARI}^{*}$ & $2.2(0.7-15.2)$ \\
\hline Flow ratio* & $2.7(1.1-8.0)$ \\
\hline $\mathrm{mPAP}(\mathrm{mmHg})^{*}$ & $29.0(12.0-99.0)$ \\
\hline
\end{tabular}




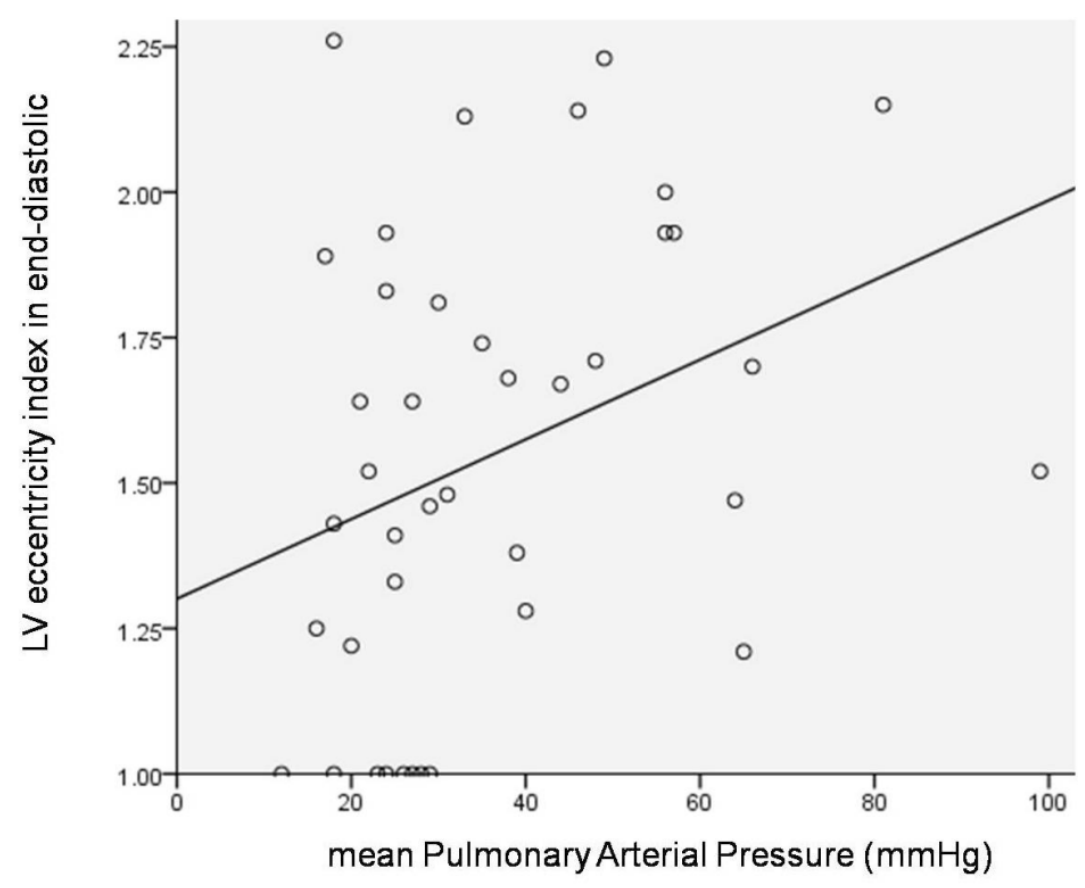

Figure 2. The scatter plot showed a moderate strength, positive and statistically significant correlation between LV EI at end-diastolic and mPAP

the El parameter, both in the end-diastolic and end-systolic, predicted the presence of PAH and estimated its severity in patients with secundum type ASD.

The differences in the interventricular septum movement can be assessed by transthoracal echocardiography. Patients with RV volume overload showed a shift in the exact of the interventricular septum away from the right ventricle in the end-diastolic phase (relative geometry of the septum is normal when the end-systolic). Whereas in the patients with RV pressure overload, it showed a shift of interventricular septum away from the right ventricle at the time of end-diastolic and endsystolic, with a more pronounced deformation in the end-systolic phase. At certain patient populations, such as patients with pulmonary arterial hypertension, the LV EI can be analyzed as a prognostic indicator of the response to therapy. ${ }^{7,8}$ Septal motion analysis can be carried out without any significant conduction disturbances detected from electrocardiogram, especially left bundle branch block. The visual assessment of interventricular septum curvature to figure the picture of the D-shaped in the systolic and diastolic phase should be used to help diagnose the right ventricular volume and/or pressure overload. ${ }^{5,9}$ By using non invasive modality, i.e. transthoracal echocardiogram, this assessment can be easily performed.

The normal movement of the interventricular septum was described by echocardiography. Ryan et al., (1986) evaluated 12 normal subjects and 35 patients who underwent cardiac catheterization to determine whether the two-dimensional echocardiography can distinguish between right ventricular volume overload and pressure overload. ${ }^{6}$ The geometry and interventricular septal motion were assessed from the short-axis view of the left ventricle. In the normal subjects, El at end-diastolic and end-systolic phase has a value of 1.0, indicating the normal circular geometry of LV chamber on short-axis view. In patients with right ventricular volume overload, El approximately 1.0 


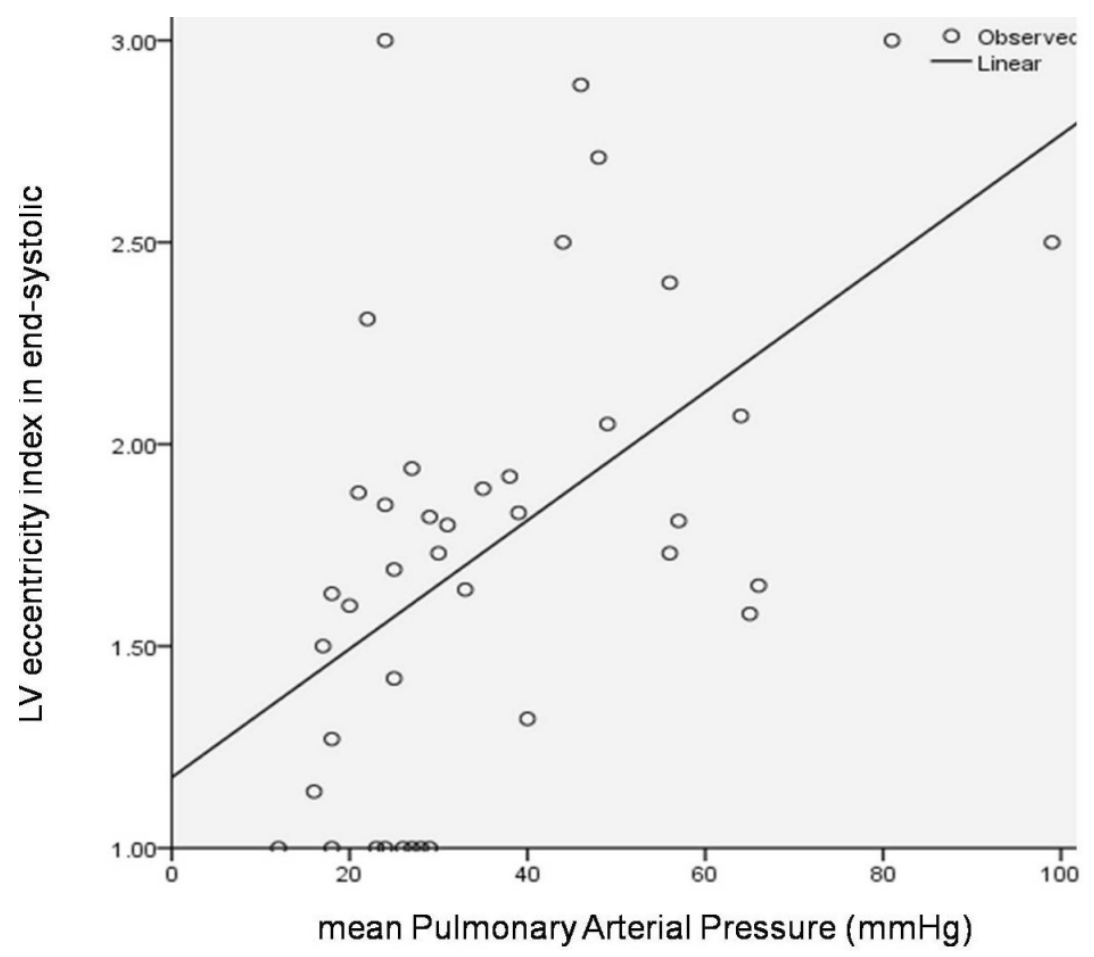

Figure 3 . The scatter plot showed a strong, positive and statistically significant correlation between LV El at end-systolic and mPAP

at the end of the systolic, but a significant increase in end-diastolic phase. In patients with RV pressure overload, the El value was significantly more than 1.0 at end-diastolic and end-systolic phase ${ }^{6}$ In this study, we have found a positive correlation between El at end-diastolic and end-systolic phase with mPAP, with stronger correlations found in the end-systolic El. However, this study did not analyze differences in El in patients with $\mathrm{RV}$ volume overload and patients with RV pressure overload.

Feneley et al., (1986) studied 16 patients with RV volume overload and 5 patients with $\mathrm{RV}$ pressure overload. ${ }^{10}$ In the group of patients with $\mathrm{RV}$ pressure overload the flattening septum incomplete during early systolic, afterward the septum began to become plateau until the end sistolic phase. ${ }^{10,11}$ In this study, they did not analyze further the changes of interventricular septum during early systolic and diastolic phase.

In the RV pressure overload, the leveling of interventricular septum occurs at the end of the systolic and resulting in an increase in El end-systolic. The El will increase at the end of diastolic in the RV volume overload condition. The LV EI end-diastolic $\geq 1.7$ indicated a worst prognosis in patients with idiopathic $\mathrm{PAH}$ due to increased mortality rate. It also indicated depressed RV function. ${ }^{12,13}$ In our study, there was a sufficiently strong and positive correlation between EI and mPAP, which indicated an increasing degree of $\mathrm{PAH}$.

This study have some limitations. In this study, we did not analyze the differences El in patients with RV volume overload and patients with RV pressure overload. Moreover, we did not analyze further changes of interventricular septum during early systolic.

\section{CONCLUSION}

In conclusion, there was a significant positive correlation between LV EI at end-diastolic and end-systolic with mPAP, with a stronger correlation 
found in the El end-systolic with mPAP. Increased $\mathrm{EI}$ end-diastolic indicated RV volume overload and increased $\mathrm{El}$ end-systolic indicated RV pressure overload. The El measurement using non invasive echocardiography could be one modality to estimate the presence and severity of PAH in patients with secundum type ASD.

\section{ACKNOWLEDGMENT}

Authors acknowledged the significant contribution of these person during the study: Monika Setiawan MD, Aristida Cahyono MD, and Sri Mardilah Wuryani AMK. Authors are indebted to cath-lab staffs and echo-lab staffs of Dr. Sardjito Hospital, Yogyakarta.

\section{REFERENCES}

1. Ascah K.J., King M.E., Gillam L.D., Weyman A.E. 1990. The effects of right ventricular hemodynamics on left ventricular configuration. Can J Cardiol, 6:99-106.

2. Diller G.P., Gatzoulis M.A. 2007. Pulmonary vascular disease in adult with congenital heart disease. Circulation, 115:1039-1050.

3. Galie N., Hoeper M.M., Humbert M., Torbicki A., Vachiery J.L., Barbera J.A., et al. 2009. Guidelines for the diagnosis and treatment of pulmonary hypertension. Eur Heart $\mathrm{J}$, 30:2493-2537.

4. Bossone E., Bodini B.D., Mazza A., Allegra L. 2005. Pulmonary arterial hypertension, the key role of echocardiography. Chest, 127:1836-1843.

5. Rudski L.G., Lai W.W., Afilalo J., Hua L., Handschumacher M.D., Chandrasekaran K., et al. 2010. Guidelines for the echocardiographic assessment of the right heart in adults: a report from the American Society of Echocardiography. J Am Soc Echo, 23:685-713.
6. Ryan T., Petrovic O., Dillon J.C., Feigenbaum H., Conley M.J., Armstrong W.F. 1985. An echocardiographic index for separation of right ventricular volume and pressure overload. J Am Coll Cardiol, 5:918-927.

7. Galiè N., Hinderliter A.L., Torbicki A., Fourme T., Simonneau G., Pulido T., et al. 2003. Effects of the oral endothelin-receptor antagonist bosentan on echocardiographic and Doppler measures in patients with pulmonary arterial hypertension. J Am Coll Cardiol, 41:1380-1386.

8. Raymond R.J., Hinderliter A.L., Willis P.W., Ralph D., Caldwell E.J., Williams W., et al. 2002. Echocardiographic predictors of adverse outcomes in primary pulmonary hypertension. J Am Coll Cardiol, 39:12141219.

9. Oh J.K., Seward J.B., Tajik A.J. 1999. Pulmonary hypertension. In: The Echo Manual, 2nd ed. Philadelphia: Lippincott Williams and Wilkins, pp. 215-222.

10. Feneley M., Gavaghan T. 1986. Paradoxical and pseudoparadoxical interventricular septal motion in patients with right ventricular volume overload. Circulation, 74:230-238.

11. Beppu S., Izumi S., Nagata S., Park Y.D., Masuda Y., Sakakibara H., et al. 1984. Ventricular interdependence reflected in interventricular septal motion: with special reference to right ventricular pressure overload. J Cardiogr Suppl, 3:53-62.

12. Howard L.S., Grapsa J., Dawson D., Bellamy M., Chambers J.B., Masani N.D., et al. 2012. Echocardiographic assessment of pulmonary hypertension: standard operating procedure. Eur Respir Rev, 21:125, 239-248.

13. Gary W., Michael A.G. 2006. Atrial septal defect in the adult: recent progress and overview. Circulation, 114:1645-1653. 